\title{
IDÉIAS
}

cracia perfeita, e exemplos disso nảo faltam no mundo. Evidentemente, o que é inadmissivel é o centralismo exagerado, ou excessivo. Extrema sunt viciosa, virtus in medio est. Temperese o excesso e a federação brasileira ficará fortalecida e aperfeiçoada, sem se cair no exagero oposto e reduzir além dos limites, o poder central. E sempre necessário lembrar que a centralização das decisões normativas ou das diretrizes governamentais não impede que se descentralize a execução de tais decisões, desde que as normas ou diretrizes levem em conta a grande variedade das situações reais encontradas nas regiões ou localidades de características bem diferentes, umas das outras. Em certas ocasiões, melhor do que descentralizar é desconcenlrar, porque, pela desconcentraçảo, ganham-se as vantagens da descentralização, sem se correr os grandes riscos dela decorrentes. Tais riscos, à evidência, são ponderáveis porque, se o País já vive a democracia real, as instituiçōes democráticas brasileiras, com ênfase especial para os partidos políticos, estão ainda em fase de transição, para seu aperfeiçoamento completo.
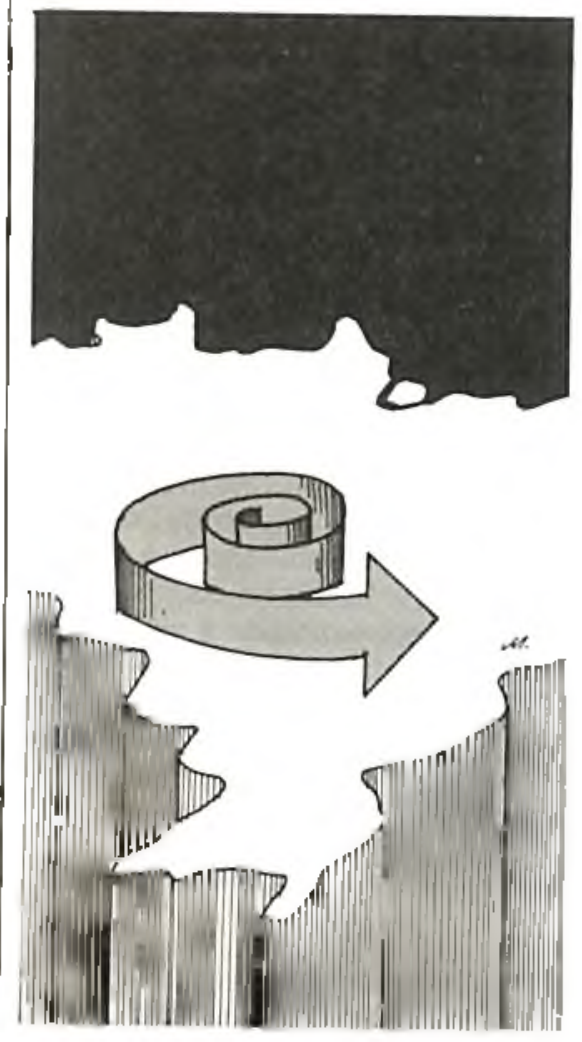

\section{A Universidade no apoio à Reforma}

\section{José Raymundo Martins Romêo (*)}

$\mathrm{R}$ eformar é conseqüência natural do processo de mudanças sociajs e do avanço técnico-científico que interagem na sociedade. Em decorrência, crescem a demanda e as exigências qualitativas na prestação de serviços público.

A administraçāo buscou na teoria sistêmica absorver essas influências e resgatá-las, dotando o complexo organizacional da necessária nexibilidade. Na prática, no entanto, é difícil implantar mudanças quando às facilidades tecnológicas disponiveis se contrapõem heranças e disfunções adquiridas ao longo da incorporação à administração pública de vícios congênitos, como a prevalência circunstancial do mérito, excessiva burocracia, insatisfaçāo salarial, diversidade de regimes juridicos, soluçōes de continuidade dos projetos saneadores, etc.

O exame dessa conjuntura, complexa por excelência, evidencia a necessidade de mobilizaçāo de conhecimento multidisciplinares. Por essa razāo, é justo ressaltar a clarividência do Ministro da Administraçāo, Aluízio Alves, ao propor o engajamen-

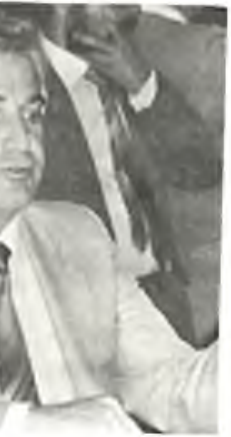

to do potencial das Universidades no esforço para sanear a administraçảo pública federal e lhes assegurar efetividade no desempenho da nobre missão de servir ao usuário dos serviços públicos.

Em abono da competência e da propriedade da mobilização das ofjcinas de trabalho intelectual e instrumental disponivel nas Instituiçôes de Ensino Superior (IES), podemos citar: a) situam-se em todas as unidades da Federaçāo e sob diferentes matizes culturais e organizacionais, desde instituiçōes públicas e privadas até a opçāo por áreas de excelência; b) dispōem de recursos humanos, instalações e equipamentos capazes de, a curto prazo, produzir diagnósticos, multiplicar as experiências de treinamento e implementar e avaliar as mudanças; c) possuem aguçada consciência crítica, de modo que o Ministério da Administração passaria a dispor de permanente ótica realista do desempenho das ações implementadas, recebendo, ao mesmo tempo, críticas e sugestōes objetivas quanto aos resultados alcançados.

Com a Nova República, os brasipresidenle do Conselho de Reilores das Universidades Brasıleiras 
leiros deram-se as mãos numa expressão máxima de reconhecimento de que chegou a hora de mudar. $\mathbf{E}$ o cidadāo está na expectativa de constatar se algo mudou, isto é, se das palavias envolvidas pelo espirito público surgirāo de fato conseqüências práticas.

Por essa razāo, é preciso responder ao povo com medidas prioritárias capazes de viabilizar a reversão da imagem do Serviço Público Federal.

Nessa linha de raciocinio, destacamos dois programas:

a) Atendimento ao usuário;

b) Produção do serviço público.

A implantaçāo dos projetos decorrentes desses programas permitirá ao Governo Fcderal e ao Ministério da Administração, em particular, atingir objetivos e desenvolver projetos que se situam nas seguintes áreas de interesse:

1. Pôr em prática nas clientelasalvo a metodologia da identificaçāo e soluçāo participativa de problemas e disfunções;

2. Desenvolver projetos que facilitem a consecução da política de pessoal do Serviço Público Federal;

3. Acompanhar, avaliar e realimentar essa assistência técnica.

A eleiçāo dessas prioridades, bem como a indicação das áreas de atuaçāo, não devem ser vistas como excludentes das recomendaçōes oferecidas pela equipe técnica que honrosamente integramos, responsável pela implementação da reforma administrativa. Ao contrário, achamos que as conclusões dessa equipe devem e podem mobilizar os segmentos representativos da comunidade em busca da efetividade do "slogan" Muda Brasil.

Muitas sāo as cobranças feitas às universidades brasileiras. Esquecem seus autores que os centros universitários foram marginalizados dos estudos e principais decisōes governamentais nos últimos decênios. Nāo obstante as restriçōes orçamentárias e cerceamentos ao exercicio da aulonomia universitária, as instituiçōes de Ensino Superior continuaram resistindo e tiveram e têm papel decisivo, como certamente terāo a Nova República, graças a convites, como o do Ministro Aluizio Alves, para contribuirem na reforma administrativa federal.

\section{Sem intenções paternalistas}

\section{José Calheiros Bomfim (*)}

A

Câmara IV da Comissāo Geral da Reforma Administrativa, em esforço concentrado, concluiu, em setembro de 1985, a elaboraçāo do anteprojeto do Estatuto dos Funcionários Públicos Civis da União, desincumbindo-se, assim, de sua basilar atribuiçāo, ao grupo outorgada pelo Regimento Interno da Comissão Geral. Todavia, por motivos impertinentes, a propos1a formulada pela referida Câmara, da qual tive a honsa de exercer, até a apreseniaçāo do trabalho ao Sr. Minist ro, o encargo de vice-presidente, passou a ser submetida a outros canais de revisāo ou "ajuste", embora estranhos à área reservada à competência do citado IV Grupo.

Oportuno grifar que, na elaboraçāo do anteprojeto, a Câmara IV ateve-se exclusivamente à orientaçāo traçada pelas diretrizes aprovadas pelo plenário da Comissão Geral, na memoriável reuniāo do mês de julho de 1985, as quais, dentre muitas outras definições, estabeleceu que a proposta deveria considerar: dignificaçāo da funçāo e do servidor público, através de tratamento inclusive salarial do agente; incorporação, aos direitos e vantagens do servidor público, das conquistas legais e dois julgados administrativos e judiciais, posteriores ao Estatuto de 1952; tratamento igualitário do pessoal civil, ativo e inativo, observando-se o princípio da isonomia, este de natureza constitucional.

Por isso que, em nenhum momento, a Câmara IV visou à concessāo de benesses, nem aluou com espirito ou intençāo paternalista. Tāo-somente se conduziu autônoma e soberana no tratamento das matérias sob sua responsabilidade, estritamente afinada com os ditames da moderna política de tratamento de recursos humanos e em rigorosa consonância com os princípios fixados nas já mencionadas diretrizes, estabelecidas pelo $\mathrm{Co}$ legiado diretivo da Comissāo Geral da Reforma Administrativa.

Assim, fiel às suas atribuiçôes, encargos e responsabilidades, a IV Câmara bem se houve no cumprimento do dever, apresentando à apreciaçāo do Sr. Ministro sua proposta estatutária, no prazo quc lhe foram cometido no cronograma da sistemática do ambicioso projeto da Reforma Administrativa.
: J José Calheiros Bomfim é membro da IV Câmara da Comissão da Relorma Admınıstrativa, represenlando a Assocıação Brasileıra de Imprensa, de que é direlor-juridico 